\title{
An International Perspective on Fluency Disorders
}

\author{
内須川 洸
}

言うまでもなく国際音声言語医学会が，かが国で開催 されるのは初めての体験であり, 組織委員の 1 人として その成功を期したが，実を言うと予期的不安も感じてい た. しかし終了してみれば若干の問題はあるかもしれな いが，諸外国からの評判もまず上々のようであったし， 筆者の専門部会である「吃音」の領野でも予期を越えて 多数の研究発表が寄せられたことは喜ばしいニュースで あった．編集委員会から筆者に与えられた課題は，第20 回国際音声言語医学会を顧て特に「吃音」に関する official report とそれに関連した Round table および 学会諸状況を報告することにある. 誌面の都合上詳細に わたっての報告は無理であるが，印象を交えてご紹介し たい.

昭和 61 年 8 月 5 日, 大会 2 日目の午前 9 時より約 2 時 間にわたって, Drs. Stounaras, F. E，(オランダ) を議 長にして，Dr. Gregory，H.H. の主題講演が実施された 後, IALP 会長 Dr. Butler, K. G. による故 Dr. Sheeahn J.G. の過去の輝かしい業績に対する名誉をたたえる表 彰式が Mrs. Sheehan, V. M. を演台上に迎えて数分間 行われ，花束がプレゼントされ，満堂の拍手を浴びた.

引き続いて, Mrs. Rustin, L. (英国) を司会者とし て, 壇上の 4 人の研究者による Round Table Discussion が実施された. 各自数分ずつ, 主題講演に対するコメン トと各自の治療・研究に対する紹介を合わせて話し合わ れたのち，Floor からの質疑応答がなされた．時間が 切迫し十分な討議は困難であったのは残念であったが， その要点を抄録し若干の所感を以下に記す。

\section{Official Report; Stuttering : A Contemporal Perspective (吃音 : 現在における展望)}

詳しくは Folia Phoniatrica, Vol. 38, No. 2-4, 1986 にゆずるが，その要点と評価について述べる. グレゴリ 一博士 (ノースウェスターン大学教授) による講演テー マは「現在における吃音の展望」であるが, 正確には,
吃音, 主として幼児吃・学童吃の診断・治療に関する諸 要因について，1940年代以降現代迄の研究実 績を概 観 し, 文献および資料を中心にして論評したのち, 現在述 べうる結論を明示したものである. 診断 (evalnation) と治療 (treatment)に関連する諸要因として, グレゴリ 一の列挙した項目は次の通りである.

現在はまだ吃音の原因を確信することができないが， できうることは吃音行動並に吃音者の諸特性についてで きうる限り正確に記述し，そこから引き出されらる情報 から吃音の診断・治療に関する要因を発見することであ る.

\section{1）吃音に関する家族歴}

長年の間，家族に吃音者をもつ場合の方が，そうでな い場合と比べて，吃音が明らかに多発することが知られ てきた.これは言語に対する態度によると考えられる一 方, 近年, Kidd $(1980,1983)$ によれば, ある吃音者に はより遺伝的要因を想定した方が妥当と考えられてお り, 環境と遺伝との相互関係と考えられる傾向を肯定し ている.

\section{2）吃音者の聴覚的過程}

吃音者には微細な聴覚的中枢過程に差異があるという 問題には, 結論を出し得ない. 非吃音者も吃音者も, こ の面に個人差がある，すなわち異質グループを内包する といら観点からさらに母集団を拡大し検討を深める必要 がある.

3) Voice Reaction Time (VRT)

刺激手掛りに引き続き反応が惹起されるまでの時間 （VRT）については，吃音者は遅れがちだといら研究が 精密な測定条件下で確認され, 近年注目されたが, 他 方, 5 歳または 8 歳以下の吃音児には正音児と比べて, とくに有意差を発見できないといら研究もあり, 結論を 出しにくい.

\section{4) Voice Onset Time (VOT)}

吃音者の VOT は非吃音者に比べて, 有意に遅滞する といら見解は，1974年 Agnello etal によって発表され て以来, 各種の研究が発表されてきたが, 現時点では結 
論を出しにくい. 被験者の人数, 手続きの相違, 結果の 変動性などの諸点が不明確であること.もしあるとして も微少であることから，VRT の場合と同様に吃音者群 のなかにも異質集団を想定しなければならないように思 われる.

\section{5）吃音の生理学と吃音者の流暢性発語}

過去15年間にわたり, 筋電図学的・電気喉頭図学的諸 研究が精密な実験条件下で進められて注目されている.

とくに吃音者の流暢な発語時でも, 無声音の発声時に筋 電図学的異常がみられた, Conture (1984) の研究では, 幼児期における不規則な音節の繰り返しと引き伸ばしの 増大に関連する発達上の個人差は注とんどみられないと 述べられている. しかしそれが吃音行動と明示しうるか も困難である。

\section{6）吃音者の言語学的過程}

近年, 臨床家や教師らは, 言語 (language) の口頭表 出の発達と音声言語の非流啺性との関係について観察 し, 吃音児には言語発達遅.帯や構音による問題を示す場 合が多いと指摘している. 一方, コミュニケーション過 程における思考, 言語選択, 文法などが流暢性に及洔す 諸特性にますます注目している.

\section{7）言語（language）要因と非流暢性}

幼児の正常発語または吃音における非流暢な発語に関 する従来の研究から多くの場合, 発語に際して, 文脈の 中で機能語 (function words) や前置詞 (pronouns) に予想以上の非暢性が見られる. 吃音や非吃音のいずれ の場合でも, $4 \sim 8$ 歳にかけての幼児では, 機能語や前 置詞において非流暢性が起こりやすい。 それからさらに ひどい非流啺性に移行したり, 内容語 (content words) に扔いてさらにどもるように変化するが, この移行現象 の特性についてさらに研究が必要である.

\section{8) 言語 (language) 要因と吃音}

従来の諸研究, 諸調査, あるいは臨床的経験のいずれ でも，吃音児には構音や言語 (language) 上の問題がし ばしば生じやすいといわれているが, Johnson (1959) は吃音児をもつ母親の吃音に対するより厳しすぎる評価 の傾向の反映と考えてきた. また Starkweather と Gordon (1984) 湆，吃音派生された人為的な所産か もしれないと考える一方, Kidd (1983) は吃音の底流に ある遺伝的素因の 1 つかもしれないと考えている. 言語 上のさまざまな局面, すなわち文法, 意味, 語用などの 吃音への組織的観察を通して, 吃音に関するすべての変 数を究明することは所詮困難である.

\section{9）環境的諸要因}

吃音に関する環境の影響については, 従来から重視さ れてきたが, 最近では, 環境要因を一義的なものとみる
よりは, 生理学的傾性との相互関係の中で容認する立場 を支持する学者が多い，遺伝的要因を肯定する立場の学 者 (Kidd, 1983) すら環境との関連を仮定している. 1960年代の初め頃から, 吃音をオペラント行動とみる学 習論の立場が隆盛をきわめたが, 近年, 環境条件を親子 関係行動として客観的方法を適用する諸研究が発見され る. (Kasprisn 1970, Kasprisn-Burrelli, Egolf, and Shames, 1972. Mordecai, 1979, Meyers and Freeman, 1985)

\section{0) 脳波学的知見 (EEG)}

最近の吃音に関する脳波学的研究知見によれば, 障害 を示すと考えるよりも, 半球機能差の問題と考えてい る. すなわち, 正常群では左半球に生ずる $\alpha$ 波が吃音群 には右半球により多く生ずること. 吃音治療後には, $\alpha$ 波が右半球から左半球に変化する. (Boberg, Yendall, Schopflocher and Bo-Lassen, 1983)

Gregory は, 吃音の診断・治療に関連するさまざまな 要因を以上 10 項目にわたり分析した結果, 論評を加え て, 彼自身の「吃音の診断・治療に関する情報の意味」 について以下のように述べている.

吃音児・者自身および環境の変数が相互に関連して吃 音の発達をもたらす. 吃音者自身の変数のうちもっとも 基本的要因は, 遺伝的傾性と思われる. その他は聴覚 的, 運動的, 言語学的または半球機能差が遺伝的要因に 反映するのであろう. 環境的変数は吃音者の経験される 多くのコミュニケーションならびに対人的関係刺激群で ある. 聴覚的・運動的・言語学的諸要因かつ親子関係が 主要なものと思われるが, 吃音の正確な原因はいまだに 不明と言わざるを得ない. 不明膫な言い方であるが，吃 音の本質も障害の治療法もきわめて複雑性に富むもので あることを熟知して，吃音児・者の診断・治療に当たっ ては, 臨床的経験によってそれらの諸要因を症例に即し て操作し，改善を計らなければならない。

\section{診断について :}

吃音群は異質群 (heterogeneous group) と現在考え るようになったが，下位群に類別しらる試みは行われた が, 現在のところ成功していない. Andrews and Harris （1964）は，4 下位群に因子分析の結果区分した. (1)遺 伝的因子, (2)言語発達遅滞因子, (3)家庭環境貧困因子, (4)知的機能貧困因子であった. Gregory は, Riley and Riley（1979，1983）の提唱する吃音の発達に関する 9 因子に基づいて，まず鑑別診断 (differential evaluation) を進めている，それにより，幼児吃音の治療には，3つ の治療水準を提示している.

水準 1 は, 予防に中心を置き, 臨床家と両親が幼児の 流暢性をモニターしながら, 両親に対して適切なコミュ 
ニケーションについてカウンセリングするものである.

水準 2 では, 関係因子の深部まで関与し, 吃音児の治 療を強力に実施するもの.

水準 3 は, 水準 1 ～2 治療を継続しながらとくに吃 音児の非流暢性を修正するために直接に介入して治療す るものである.

\section{治療について :}

幼児の治療については, 臨床家は次の 4 領域に焦点を 当てて実施することを勧めている.

(1)環境におけるコミュニケーション上の緊張を減少 させる，たとえば両親の吃音児に対する話し方や 速度を調整するなど

(2)対人関係の緊張を減少させる.たとえ嫁族関係 の調整をはかるなど

(3) 声語学的・運動的発達差に対する配慮

(4) 言語の流暢性

また, 学童後期または成人の固定化した二次性吃音者 (confirmed secondary stutterer) に対する治療には, 治療過程の中で十分に態度の改善をはかり, 吃音に直面 させ，より滑らかにどもれるように徐々に行動を修正し ていく.それとともにより滑らかに話せるように種々の 対症療法を使用していく, a stutter-more-fluently の方 法と, a sperk-more-fluently の方法とを併行して実施 する方法を提唱している. 最終段階では, 流暢な発語状 況を日常活動に移行させ定着をはかる方法である.

\section{結 論 :}

1965年 IALP の主題講演として採択された吃音問題 以来, 20 年間にさらに明確化された非流暢性と吃音に関 する情報について, とくに発生的要因, 聴覚過程要因, 発語運動要因, 言語学的要因, 環境的要因および大脳半 球機能要因が簡略に論評分析された. 吃音問題の性格お よび治療方法沈きわめて複雑であることがますます明ら かとなり, これらの情報に基づて, 臨床家は臨床的知 見を活用しつつ, 診断・治療上の手続を構造化しなけれ ばならない.すなわち, 鑑別診断・鑑別治療モデル（a differential evaluation-diffential treatment model) を利用しなければならない。この点, 現在では成人吃音 よりも発吃まもなくの幼児吃音に関しては，さらにその モデルは明瞭となってきた. 以下の 4 点は治療問題にと って特別な考慮の対象となった. (1)環境調整, (2)学童後 期以降の吃音者にとってより流暢にどもるか話すかの論 争, (3)治療に打ける態度とその変化の評価, (4)クリニッ ク内の変化を実際生活場面に有効に移行させ常に維持す る問題.

以上のごとく，Dr. Gregory は，主として過去20年間 におけるさまざまな要因, とくに吃音の発達や非流暢性
に係わる諸要因に関する研究状況を文献並に資料に基づ いて分析論評したうえ, 吃音の診断・治療に活用可能な 知見を的確かつ簡潔に次のようにまとめている.

「臨床家にとって, 今こそ differential evaluationdifferential treatment model が必要である」

この見解は, 現在, 幼児吃音の診断・治療問題に関す る限り,きわめて妥当な時宜に即したコメントと評価さ れよう。

\section{Round Table Discussion（円卓討議）}

壇上に, 内須川洸 (日本), Dr. Butler, K. G. (米国), Dr. Becker, R. (東独), Dr. Damste, H.P. (オランダ) の 4 名の発言者が並び, 司会者の Mrs. Rustin による 紹介の後に, 着座順に従って始められた. 各発言者の内 容について, ごく手短かに紹介し，その後討論にふれ る.

内須川は, Dr. Gregory の吃音の診断と治療に関する きわめて簡潔かつ明解な示唆に富む発表に対する敬意を 述べた後, 彼の主唱する「多くの臨床家は, 現在におけ る吃音の本質 (nature) に関する知識を総動員して, a differential evaluation-differential treatment model を作るべきである」という提案に賛意を表した. しかし 如何なるモデルを作るかが問題であることを指摘し，内 須川が現在実施している「幼児吃音」に関寸る診断・治 療研究の試みを紹介した. 従来, 事例研究や多数症例の 集積から吃音の治療に関する特徴や傾向を吟味する諸研 究はみられても, 明確な知見は得られなかったので, 本 研究では初めから意図的計画的に, 幼児吃音を吃音歷 ( 1 年), 発吃型 (突発型), 家族構成 (両親と兄弟 2 人), 循環性, 治療経験 (なし), 発吃年齢の 6 条件を統制し て選択し，1 力年の治療期間内で治療実験を実施する方 法を提示した.

Dr. Butler, K. G. (米国) は, Dr. Gregory が講演の なかでふれた言語要因と吃音問題に関して同様な経験を 臨床的に確認している旨の発言をした. とくに構音に問 題をもつ吃音児が多いのではないか指摘された。

Dr. Becker, R. (東独) は, 東ドイツ, フンボルト大 学附属臨床クリニックにおける言語臨床のあり方につい て発言し，次のような特徵を指摘した. 主として幼児お よび低学年学童児の診断評価に当たっては，各種の専門 家, 小児神経科医, 児童精神科医, 言語病理学者, 心理 学者, ケースワーカー, ナース, 教師などのチーム・ア プローチが必要である. とくに突発性吃音に当たって は, (1)言語発達の一般状況, (2)吃音児の言語学的水準, (3)認知成績, (4)特殊な精神医学的特異性, (5)社会性の異 
常などの診断が重要である.このため Heidelberg Language Development Test, speech performance scale, Raven's CPM, や各種の analogy test, また, 脳波的 異常や神経症傾向質問紙などを使用して, 各症例の特徴 をできるだけ正確に記述し，鑑別評価するようにしてい ると述べた.

Dr. Damste, H.P. (オランダ) は, 吃音と遺伝的要因 に関する問題に視点を当て, Kidd, K (1983) の Recent progress on the genetics of stuttering の研究を取り 上げて次のごとく発言した. 両親のいずれかに吃音をも つ子供の吃音の出現率が78\%を示すことは, 遺伝的要因 を無視できない. 最近では胎児も超短波診断が可能の時 代だから, 将来, 母親のリズムや感情の影響が胎児にい かなる結果を示すか研究できるのではないだろうか. ま た，遺伝的要因と環境との関連はどうかが問題であるこ と, 家族の中にその要因を発見する試み，より予防的方 法を探索することなどが重要であろう.

これら 4 人の研究者の発言の後に, フロアーからの質 問が寄せられたが，時間が切迫しているので数名に限定 された。

吃音の予後の問題, 自然治㾙の問題, 二力国語同時使 用と吃音問題, 吃音児の親に問題がある場合どのように 対処するかなどの質問があった. これらの討論の詳細は 割愛せざるを得ないが， $2 ， 3$ の印象に残った問題につ いて述べよう. Dr. Gregory に対する質問で吃音の予 後, 自然治瘾について, 非常に重要な問題であること. 親が吃音ではないかと心配に思う場合には，できるだけ 早期にスクリーニングを行う. 非流暢性の程度がごく軽 度の範囲を出ないときには, 親を中心にしてカウンセリ ングを実施し，環境調整を中心と考える．長期に及ぶも のは 6 力月間持続するものもあるが, 特別な要因のない 場合には $4 \sim 8$ 回程度のセションで終える場合もある. 非典型的症例や重度の症状をもつ症例では, さらに長期 的加療を必要とし, 両親と子供の両方に Counseling と 治療を実施する。

Mrs. Rustin から，この問題に関して次のような勧告 があった. 親に問題がある場合には自然治浼の割合は少 ないように思う，治療を始める以前に，親の諸問題に鑑 別評価を詳細に実施する必要がある. Mrs. Rnstin のと ころでは，親子ともに 2 週間にわたって，言語状況のみ ならず，家族関係，吃音児と両親の関係，吃音と親の性 格特性, 遺伝的要因などにわたり詳細に評価したのち治 療法の検討をする. そのため臨床家には専門的訓練が必 要であること. そして養成の専門ュースが必要である提

（注）現在，国際吃音委員会は各国からの代表委員11名から 構成されており，議長は Drs, Stournaras である.
唱を行った.

最後に主題講演の議長, Drs. Stournaras は吃音の性格 と治療法に関するきわめて複雑な特徵が, 吃音の診断と 治療上の難点になっている点を指摘して，この克服のた めには, 吃音に関する高度の専門性が必要である.IALP に属する International Committee on Fluency Disorders (国際吃音委員会) では，これに関して $5 \sim 6$ 年の うちには専門的報告書を作成したいと締めくくった. 今 後吃音の診断と治療に関する高度の専門的技能をもつ臨 床家の養成がますます必要となるであろう。

\section{吃音に関する一般演題について :}

吃音に関するわが国における研究状況は, 近年その研 究発表数の面からみても減少の一途をたどってきたよう に考えられる.今年, 第20回国際音声言語医学会におい て, Main Report の1つとして, Dr. Gregory. H. H. による「吃音：現在における展望」が採用されたことは 大変有意義であった. これに伴い，吃音に関するわが国 の発表数が13に及んだことも例年にない快挙といって良 いであろう．全体では若干の変更はあったが23列を越す 発表数に上った. その詳細を記述することは紙量の関係 上困難であるので, IALP への発表要旨の詳細は, Folia Phoniatrica, Vol. 38. No. 5〜6，1986に掲載されてい るのでご参照下さい. ここでは今回国際学会に発表され た吃音研究に限り, その概要について考察し, 印象を付 記するにとどめよう．わが国における吃音発表数は全発 表数の半数を越した. 発表国別では，日本 (13)，米国 (5), 英国 (2), イタリヤ (1), 東独 (1), ポーランド （1）合計 23 にった. 対象別に分類してみると，成人 に関する研究 (12), 学童に関するもの (3), 幼児に関 するもの (8), となる. また, 基礎研究と臨床研究に区 分してみると, 基礎 (13), 臨床 (10) となる. さらに それを対象別に考察してみると, 基礎研究（成人： 8 , 学童: 3 , 幼児: 2 , 計13), 臨床研究 (成人: 4 , 学 童： 0 , 幼児 : 6 , 計10)

ここから吃音研究の今回発表分に関する限り次のよう な傾向を見い出すことができよう.

(1)成人に関する研究は基礎研究がもっとも多い.

(2)臨床研究では, 幼児に関する研究がもっとも多 い.

(3)幼児に関する研究では, 基礎研究が臨床研究に比 ベて $1 / 3$ である.

臨床研究の抬頭と, しかも幼児研究に集中してきた傾 向は, 吃音研究の新しい動向と考えることができる.

なおわが国で国際学会が初めて開催されたことを契 機に, 吃音に関する一部の発表がマスュミ機関を通じて とり上げられ公表されたことは関係者の 1 人として喜ば 
Vol. 28 No. 1 , 1987. 1

しいことであったが，その内容に一部行き過ぎがあった 印象を禁じ得なかった. 吃音の原因解明が母子関係の研 究を通じて前進したごとき印象を一般人に与えたのでは
57

ないかと恐れる. Dr. Gregory の主題講演でも述べられ ているように吃音の原因の所在を論ずるにはいまだ時期 早尚といわねばならないことを付言しておきたい. 